\title{
"NUBUAT" BENCANA DALAM SERAT SABDO PALON: Kajian Hermeneutika Filologis Terhadap Bait-Bait Tembang Pupuh Sinom Dalam Serat Sabdo Palon
}

\author{
The Nubuat of the Disaster in the Serat Sabdo Palon \\ Philological Hermeunetic Study of Tembang Pupuh Sinom Verses in Serat Sabdo \\ Palon
}

\author{
Arif Budiman \\ MAN 21 Jakarta \\ Jalan TambunRengas No. 48 RT 001 RW 07 Rorotan, Cilincing Jakarta Utara 14140 \\ E-mail: arifbudiman@man21-jkt.sch.id
}

\begin{abstract}
At the end of the 20th century and the beginning of the 21 st century, we continue to be presented with facts about massive disasters ranging from volcanic eruptions, the 2006 Aceh Tsunami until the issue of megatrust that has been released by the ITB research team in collaboration with $B M K G$. These are a series of real disaster facts. Finally, the fact that the disaster that has hit this one year, namely the Covid-19 disaster is not only a local disaster but this disaster has become a global disaster. Experts are working hard to analyze this disaster or epidemic. Geologists see this disaster from his perspective. WHO views this disaster as the spread of a variant of the corona virus called COVID-19. This study seeks to present disaster mitigation through the study of ancient manuscripts. The research method uses philological hermeneutics, so that the contents of this manuscript will be explored. This Serat predicts that these years will be a disaster, and the cause of this disaster is due to human activity. The explicit and implicit meaning of disaster in the Serat (ancient book) is a new treasure that needs to be presented or introduced to our generation. Aside from being a human warning, this research can be presented as an opening for further research.
\end{abstract}

Keywords: Filological Hermeneutic, Nubuwat, disaster, Sinom-Pupuh and Serat Sabdo Palon

\begin{abstract}
Abstrak
Di akhir abad ke 20 dan awal abad 21 terdapat fakta bahwa bencana yang massif mulai dari gunung meletus, Tsunami Aceh tahun 2006 hingga isu megatrust yang telah dirilis tim riset ITB bekerjasama dengan BMKG adalah sederet fakta kebencanaan yang nyata. Terakhir, fakta bencana yang telah melanda satu tahun ini yaitu bencana Covid-19 bukan hanya menjadi bencana local tapi bencana ini telah menjadi bencana global. Para ahli bekerja keras menganalisa bencana atau wabahi ni. Ahli geologi melihat bencana ini dengan perspektifnya. WHO memandang bencana ini sebagai penyebaran varian virus corona yang dinamakan Covid19. Penelitian ini berusaha menyajikan mitigasi bencana lewat kajian naskah kuno. Demi mendalami atau menggali kandungan naskah, penelitian ini menggunakan metode hermeneutika filologis. Serat ini meramalkan bahwa tahun-tahun ini akan terjadi bencana, dan sebab bencana ini terjadi karena ulah manusia. Makna bencana yang tersurat dan tersirat di dalam Serat (kitab kuno) adalah khasanah baru yang perlu disajikan atau dikenalkan kepada generasi kita. Selain sebagai peringatan manusia, penelitian ini dapat dihadirkan sebagai pintu pembuka bagi penelitian-penepitian selanjutnya.
\end{abstract}

Kata Kunci: Hermeunetika-filologis, Nubuat,Bencana, Sinom-Pupuh dan Serat Sabdo Palon 


\section{PENDAHULUAN}

Fakta tentang bencana di Nusantara, yang ada di awal abad 21 ini demikian mengguncang sisi-sisi kemanusiaan. Fakta ini membentang dari Tsunami Aceh tahun 2006 dan sambung menyambung dengan gunung meletus tahun 2010 di Yogyakarta, Tsunami di Pangandaran, Lumpur Lapindo tahun 2014, tsunami di Banten tahun 2018, tanah bergerak di Palu, gempa di Ambon hingga ketakutan atau kekhawatiran akan adanya isu megatrust yang telah dirilis tim ITB bekerja sama dengan BMKG adalah sederet fakta kebencanaan yang nyata. Terakhir, sebelum rilis hasil penelitian tentang megathrust, bencana penyebaran Covid-19 sejak awal tahun ini nyata mengoyak sisi kemanusiaan baik dalam tampilan ekonomi, sosial, dan budaya. Terlepas dari apakah Covid ini akan dianggap sebagai fakta ataupun teori konspirasi, realitasnya kegaduhan sosial tak terelakan, kegoncangan ekonomi menerjang. Dari sini timbul pertanyaan utama, mengapa bencana itu terjadi di tahun-tahun ini atau di abad 21 ini. Adakah kaitan bencana-bencana ini dengan naskah kuno Serat Sabdo Palon?

Maka yang perlu dilakukan adalah penelitian yang berusaha memberikan jawaban atau rekomendasi untuk mencegah aneka bahaya atau bencana. Serangkaian tragedi kemanusiaan adalah ulah manusia yang lalai dalam menjaga alam dan lingkungannya. Damar Shashangka dalam bukunya "Sabdo Palon: Kisah Nusantara Yang Disembunyikan". menerangkan tragedi dan bencana yang terjadi selama ini disebabkan oleh sentimen kepercayaan (Shashangka, 2016). Aksi fundamentalisme agama menyeruak ruang-ruang publik dan mengoyak makna spiritualitas menjadi sesuatu yang mengerikan. Agama Islam yang rahmatan lil alamin tampil menjadi agama yang menghalalkan pembunuhan. Azyumardi Azra menyebut aksi fundamentalisme agama ini dengan istilah tindakan sektarianisme berupa pengeboman tempat ibadah, makam tokoh agama, pasar dan jalan raya (Azra, 2016). Sabdo Palon 500 tahun lalu sudah memberi peringatan dalam bentuk ancaman atau nubuat bencana. Sabdo Palon mengatakan bahwa jika perjalanan kuasa (politik, agama, dan budaya) di tanah Jawa tidak amanah maka akan kembali dengan tanda-tandaaneka bencana yang melanda. Jadi, semestinya manusia zaman sekarang memperhatikan ancaman ini dengan memperhatikan karya sastra bangsa sendiri tentang mitigasi bencana.

Serat Sabdo Palon menceritakan dialog Sabdo Palon dengan Sunan Kalijaga dan Brawijaya. Berdasarkan sumber yang terdokumentasikan yang berujud tembang (Anonim, 1958). Syeh Subakir adalah syeh penyebar atau pendakwah ajaran Islam di tanah Jawa. Syeh Subakir adalah ulama atau Wali Sanga generasi pertama yang ditugaskan oleh Sultan Mahmud I dari Kesultanan Turki untuk menjalankan misi pengIslaman. Sebelumnya sudah ada ulama dengan misi yang sama namun gagal, karena diganggu dedemit atau mahluk halus yang mendiami tanah Jawa. Syeh Subakir dianggap memiliki kemampuan supranatural maka bekerjalah menjadi penumbal Gunung Tidar atau tempat-tempat lain yang dianggap ditinggali aneka mahluk gaib.

Sementara itu, Babad Tanah Jawa menyebut Syeh Subakir sebagai utusan

Sulthan Mahmud I dari Turki dengan misi peng-islaman. Ia memasang jimat (tombak Kyai Pajang atau juga disebut Rajah Aji Kalacakra di Gunung Tidar yang saat itu 
dianggap sebagai pusatnya jin di tanah Jawa (Purwadi, 2006). Maka, dengan jimat itu, kocar kacirlah para penghuni baik dedemit, kuntilanak berlarian meninggalkan Gunung Tidar. Ada yang mengatakan mereka tinggal di wilayah timurPulau Jawa,sumber lain menjelaskan bahwa tempat yang dimaksud adalah "Alas Purwo" (Kurniawan, 2020). Para lelembut selain ke Alas Purwo juga ada yang menyingkir ke laut. Melihat kekalahan ini, Semar sebagai Dahyang tanah Jawa harus mengakui kekalahannya. Ia pun pamit dari tugas yang telah diembannya secara turun temurun.

Dialog antara Syeh Subakir dengan Sabdo Palon ini menurut penulis merupakan pembicaraan idiologis sebab apa yang dibicarakan menyangkut falsafat atau pemikiran. Sabda Palon (Semar Badranaya) menyatakan menolak ajaran baru yang dibawa para wali. Meskipun ia kalah atas Syeh Subakir tapi ia tidak mau mengganti keyakinannya. Sabdo Palon pergi meninggalkan Brawijaya dan bersembunyi. Dialog akhir ini ditutup dengan wanti-wanti Sabdo Palon kepada Sunan Kali Jaga, bahwa jika suatu saat terlihat agama yang dibawa Sunan Kali Jaga justru tidak membawa kemaslahatan atau kebaikan, artinya pemimpin ataupun rakyat dengan agama baru tidak amanah, maka ia mengancam akan kembali ke tanah Jawa dan akan mengganti agama Islam dengan ajaran Budi. Adapaun waktu kedatangan Sabdo Palon adalah 500 tahun, angka ini diucapkannya sendiri. Sabdo Palon datang bersama rangkaian bencana yang melanda seluruh negeri.

Kabar dalam naskah ini adalah sebuah nubuat yang berarti berita atau peringatan. Apakah ada korelasinya bencana yang melanda bangsa ini dan bahkan dunia? Sebut sajabencana Covid-19 nyata telah melumpuhkan roda ekonomi, bandara tutup karena sepi aktifitas, PHK tak terelakan dan segudang permasalahan ekonomi dan kemanusiaan lainnya. Seandainya pesan leluhur terawat dan terindahkan, bisa jadi kita tidak akan alami situasi sebagaimana saat ini. Ke depan tentu ingin perubahan, yaitu dengan selalu berusaha menjadi pribadi-pribadi bangsa yang bertanggung jawab yang menghargai nilai-nilai dan kearifan leluhur kita.

\section{Metode Hermeneutika Filologis}

Hermeneutika filologis membutuhkan kecakapan dalam memahami bahasa yang ada dalam suatu teks. Sehingga tidak terlalu mengherankan jika penelitian ini akan mengungkap realitas zamannya dari suatu peristiwa kejadian dimana teks itu tercipta. Sebagaimana yang dikatakan Gadamer, salah satu pencetus teori hermeneutik ini menyatakan bahwa bahasa merujuk pada realitas representasi dari masyarakatnya (Palmer, 1972).

Atas kenyataan penelitian berupa teks (bait-bait) kuno berbahasa Jawa ini maka kajians erat ini menggunakan hermeneutika filologis sebagai pisau bedah yaitu membedah kata-kata (bait-bait) dialog yang tertulis dalam tembang Pupuh Sinom serat Sabdo Palon. Beberapa ahli yang dianggap pendapatnya otoritatif tentang konsep hermeneutika filologi antara lain Baroroh Baried. Baroroh menyatakan bahwa filologi dibutuhkan untuk mengkaji peninggalan berupa tulisan dari suatu kurun waktu beratusratus tahun lamanya (Fathurahman, 2016). Kedua, pendapat Sulastin Sutrisno, 
sebagaimana tercatat dalam Kamus Filologi menyatakan filologi sebagai ilmu yang menyelidiki perkembangan kerohanian suatu bangsa dan kekhususannya atau yang menyelidiki kebudayaan berdasarkan bahasa dan kesusastraannya. Sementara itu, Oman Fathurahman berpendapat bahwa penelitian filologissebagai investigasi ilmiah atas teks teks tertulis (tangan), dengan menelusuri sumbernya, keabsahan teksnya, karakteristiknya serta sejarah lahir dan penyebarannya (Fathurahman, 2016).

Berdasarkan definisi-definisi tersebut diatas, penulis merumuskan Hermneutikafilologis sebagai "upaya menggali dan menjelajahi objek penelitian dengan analisa mendalam suatu teks atau sistem kebahasaan". Oman Fathurrahman menyertakan tahap-tahap dalam penelitian filologi tahapan yang meliputi penentuan teks, deskripsi naskah, perbandingan naskah dan teks, suntingan teks, terjemahan teks dan analisis isi. Alur ini kita pakai dalam penelitian teks ini menjadi uraian langkahsebagai berikut (Fathurahman, 2016):

Pertama, penentuan teks, yaitu dengan memastikan atau menentukan teks mana yang digunakan dari Serat Sabdo Palon.Teks serat Sabdo Palon dimaksud adalah teks yang mengabadikan perbincangan antara Syeh Subakir dan Sabdo Palon dalam bentuk tembang. Dialog Sabdo Palon banyak diceritakan beberapa sumber. Sementara itu, teks yang dimaksud adalah Serat Darmogandul yang ditulis oleh Ki Kalamwadi. Identitas Ki Kalamwadi tidak jelas sehingga memunculkan kontroversi hingga sampai tebakan bahwa sang penulis adalah pujangga terkenal Jawa, Ronggowarsito. Saat ini telah ada penulisan lengkap karya klasik ini seperti yang dilakukan oleh Damar Shahangka (Shashangka, 2016).

Kedua, adalah tahap inventarisasi naskah, yaitu dengan menggali bait-bait serat pupuh Sinom dalam naskah Darmogandul dalam buku-buku atau naskah kuno. Bait-bait dalam Tembang Pupuh Sinom dapat dibandingkan isinya dengan bait yang sama dalam naskah lain. Atau pemilik atau pemegang teks asli yang menyimpan bait tembang ini. Semisal adanya versi lain yang mengungkap pembicaraan ini yang menceritakan "DialogMistikal" ini seperti serat Dhamar Wulan dan Serat Blambangan.

Ketiga, deskripsi naskah yaitu tahap menjelaskan profile naskah serat Sabdo Palon. Serat Sabdo Palon adalah karya sastra yang lahir pada suatu masa dengan keadaan tertentu. Dalam artikel Susiyanto dituliskan bahwa serat Sabdo Palon adalah karya R.Ng. Ronggowarsito. Sementara faktanya serat Darmogandul yang memuat baitbait tembang itu tidak mencantumkan penulis (anonim) (Susiyanto, 2012). Serat ini adalah naskah kuno berisi dialog idiologisnya ditulis ulang dalam Serat Darmogandul.Serat Dharmgandul ditulis hari Sabtu Legi, 23 Ruwah 1830 Jawa (atau sangkala Wuk Guneng Ngesthi Nata, sama dengan 16 Desember 1900). Serat Darmagandhul adalah suatu tembang macapat kesusastraan Jawa Baru berbahasa Jawa Ngoko. Kajian tertuju pada bait-bait tembang Pupuh Sinom yang secara umum menjelaskan suatu peristiwa politik dan juga spiritual.

Keempat, perbandingan naskah dan teks. Perbandingan dengan teks mempunyai tujuan untuk mengetahui mana yang paling valid, kedua untuk melihat konteksnya. Penelitianakanberhenti pada kesimpulan bahwa setiap Serat yang mencantumkan dialog 
idiologis ini, memiliki kesamaan dalam konten cerita yaitu mengisahkan peristiwa atau situasi pada masa-masa akhir Majapahit.

Kelima, suntingan teks, yaitu tahapan penelitian denganmenyiapkan teks yang telah diterjemahkan yaitu serat yang memuat dialog antara Sabdo Palon dengan Syeh Subakir yaitu dialog yang secara khusus menyebut kata bencana.Fokus kajian ditujukan pada Tembang Pupuh Sinom yang terdiri dari16 bait (Shashangka, 2016).

Keenam, terjemahan teks. Di alur ini, tidak melakukan penerjemahan dari bahasa Jawa ke Indonesia sebab sudah ada banyak terjemahan yang tersebar dan. Penulis hanya memastikan antara satu sumber dengan sumber lainnya memiliki kesamaan arti. Jadi pada tahap ini penulis menentukan terjemahan serat atau bait-bait tembangberdasarkan Serat Darmogandul.

Ketujuh, analisis isi pendekatan hermeneutika filologis melihat keseluruhan isi yang terkandung dalam teks tersebut.Uraian atas tahapan-tahapan tersebut pun harus dilakukan. Selanjutnya akan didapati satu benang merah kesimpulan yang kuat.

\section{PEMBAHASAN}

\section{Serat Sabdo Palon}

Serat Sabdo Palon sebagaimana serat-serat lain dalam kesusastraan Jawa Kuno tumbuh subur pada masa kerajaan Majapahit. Para ahli meyakini bahwa lahirnya Serat Sabdo Palon ketika kekuasaan Hindu-Buddha berkuasa yaitu tepatnya pada masa akhir Majapahit. Agama besar yang dianut Majapahit kala itu adalah Syiwa-Buddha maka rakyat Majapahit secara umum menganut keyakinan ini. Sabdo Palon adalah tokoh spiritual dari agama kerajaan saat itu (Shashangka, 2016).

Sebagai sebuah kajian sastra maka pemahaman konseptual tentang sastra perlu diajukan. Sastra adalah sarana dokumentasi yang mengungkapkan pemikiran, gagasan penulis pada masanya. Penelitian ini mendefinisikan sastra sebagai jiwa zaman. Hal ini merupakan pondasi penting dalam penelitian ini. Karena itulah Serat Sabdo Palon dalam Kitab Darmogandul adalah kontruksi situasi pada zamannya. Kajian filologis memungkinkan untuk melihat situasi sosial politik budaya dan keagamaan yang ada pada masanya.

Sebagai yang disampaikan Gadamer dalam buku Analisis Konten Etnografi dan Grounded Theory dan Hermeneutika dalam Penelitian, bahasa menurut Gadamer adalah realitas zamannya (Zuchdi \& Afifah, 2019). Berdasarkan hal tersebut dapat diketahui bahwa yang tertulis atau narasi dalam serat Sabdo Palon pada serat Darmogandul adalah fakta akhir kerajaan Majapahit.

Sebagai contoh jika di dalam babad atau serat itu menggambarkan raja punya kesaktian, dunia para dewa yang berkuasa di langit dan seterusnya. Kemudian ada para bidadari dan seterusnya. Itu kenyataan dalam alam pemikiran mereka atau imajinasi yang hidup pada masa kerajaan Majapahit saat itu. Cerita negeri para dewa dan seterusnya adalah kosmik masa itu. 


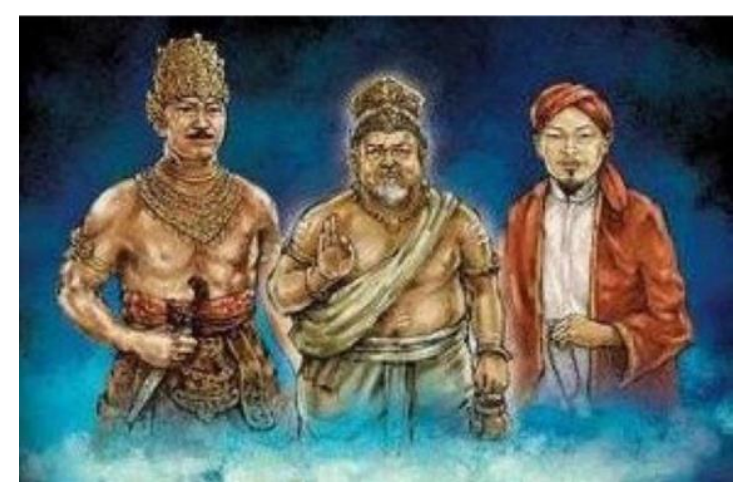

Gambar 1. Ilustrasi Sosok Brawijaya, Sabdo Palon dan Syeh Subakir (Sumber https://beritajowo.com/).

Tokoh Sabdo Palon adalah tokoh Simbolis yang digambarkan sebagai "pengemong" raja-raja Jawa dari masa ke masa bahkan sejak Nusantara ini ada sebagaimana yang diceritakan dalam Babad Tanah Jawa yaitu sejak Semar mendampingi Prabu Palasara (Purwadi, 2006).

Sebagaimana tertulis dalam Naskah Serat Pati, disana terlihat bahwaSabdo Palon bukan semata penasehat Majapahit, sebab ternyata Sabdo Palon juga menjadi Penasehat Raja di Kabupaten Pati, intinya dapat disimpulkan bahwa Semar adalah pengasuh rajaraja Jawa (Purwadi, 2006). Sebagai peristiwa masa lampau kita, bisa menggunakan disiplin sejarah sebagai alat bedah untuk memahami horizon peristiwa atau kejadian.

\section{Masa-Masa Akhir Kerajaan Majapahit}

Raja terakhir Kerajaan Majapahit adalah Raja Brawijaya V yang berkuasa pada tahun 1468 sampai dengan 1478 M. Pada masa ini, pengaruh Islam sudah mulai menyebar ke seluruh penjuru dunia termasuk Asia Tenggara, termasuk di dalamnya adalah Pulau Jawa. Hal ini tidak terlepas dari pengaruh Dewan Penyebar Islam Jawa yang intensif menjalankan misi peng-Islaman. Bre Kertabumi memegang kunci penting penyebaran Islam, ia yang meminta Raja Champa mengirimkan salah satu ulama untuk menjadi petinggi Agama Islam di Kerajaan Majapahit pada tahun 1445 M. Walau sempat mendapat perlawanan bahkan ditahan, Syeh Ibrahim Al Akbar akhirnya dapat diboyong ke Majapahit untuk menjadi petinggi agama di kerajaan Majapahit (Shashangka, 2016).

Dalam konteks sejarah, Majapahit berakhir ketika kerajaan ini mendapat penyerangan Raden Patah yang tidak lain adalah putranya sendiri. Serangan ini dibawah bimbingan dan arahan Sunan Giri yang terus mendesak Brawijaya untuk menerima Islam. Brawijaya pun akhirnya menerima Agama Islam sebagai agama kerajaan menggeser agama Hindu-Buddha. Sejak saat itulah, tahun 1478, Kerajaan Majapahit secara de factodinyatakan berakhir dan berganti kerajaan Islam di Demak dibawah kekuasaan Raden Patah. Angka inilah yang dijadikan angka awal perhitungan tentang akan kembalinya sosok Dahyang Tanah Jawa, atau Semar yaitu setelah 500 tahun di 
"persembunyiannya". Berkuasanya Raden Patah menandai berakhirnya kerajaan Hindu pedalaman menjadi kerajaan tepi pantai.

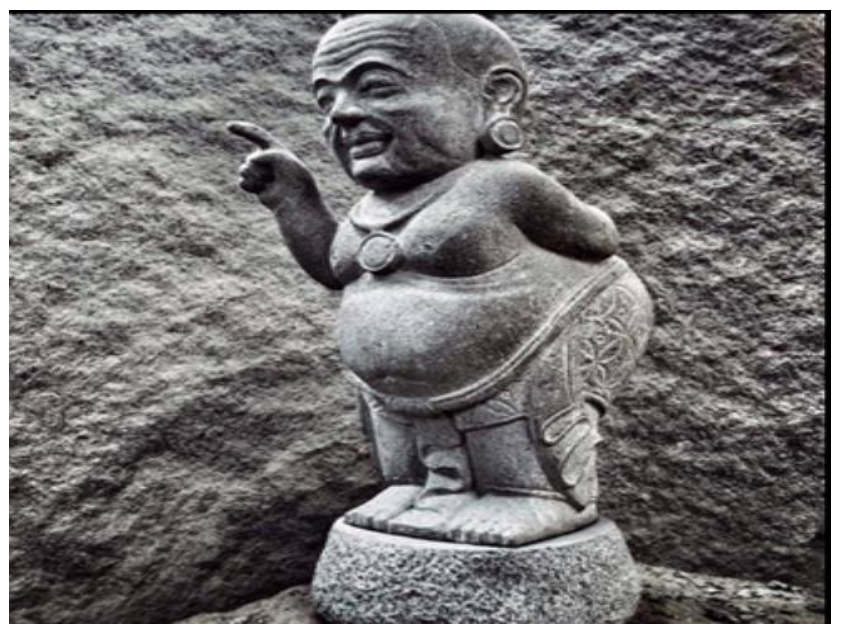

Gambar 2.Sosok Semar Dahyang Tanah Jawa (Sumber/https://www.perwara.com).

\section{Definisi Bencana dalam Kitab Suci atau Naskah Kuno}

Nubuat adalah peringatan atau pemberitaan yang sudah terlebih dulu diwartakan atau tercantum dalam teks sebelum kejadian itu terjadi. Istilah nubuat sering kita temukan, ketika membahas tema kedatangan Nabi Muhammad yang telah diberitakansebelum nabi itu datang. Berita itu bahkan telah ada atau diceritakan dalam kitab-kitab sebelum Islam baik Kristen ataupun Hindu. Dalam bahasa Arab, Nubuat berasal dari kata Annaba artinya berita. Kata benda menjadi Anubuwah artinya hal yang berkaitan dengan pemberitaan. Sang pembawa berita itu biasa dinamakan Nabi.

Tafsir terhadap serat ini yaitu terhadap tema bencana harus ditempatkan dalam konteks zamannya. Pertama yang harus dilakukan adalah tafsir apa yang akan digunakan. Tentu saja tafsir yang dilakukan adalah tafsir ilmiah dengan pendekatan hermeunetik filologis. Bukan tafsir mistik, sebab tafsir mistik tentu akan berujung pada penyimpulan yang tidak logis terhadap narasi atau penjelasan yang diberikan. Biarlah itu dilakukan para penafsir atau penggiat mistik dan pelaku kejawen.

Istilah bencana adalah istilah geografi, namun istilah ini bisa menjadi tema agama atau tema budaya. Menurut Drewes, bencana adalah musuh yang belum ditaklukan oleh Allah dan harus ditaklukan. Sementara itu Campbell-Nelson memandang bencana sebagai karya Allah yang harus diterima (Zakaria J. Ngelow, 2019). Bencana dalam definsi ini dapat disepakati sebagai satu keadaan yang tidak diinginkan yang bersifat masal yang menimbulkan kerusakan besar bagi kehidupan manusia, kematian, kelaparan atau penyakit.

Sebagai penjelas, dapat dirumuskan pengertian bencana sebagai perangkat kosmik yang menyangkut hubungan dengan Tuhan (dewa, atau kekuatan supranatural) yang digunakan untuk menjaga keseimbangan alam (Kosmik) kehidupan. Karenanya 
bencana dalam konsep ini adalah alat bagi Tuhan agar manusia kembali pada hakikat kemanuisaanya di hadapan Tuhan, yaitutaat kepada Tuhan.Maka jelas sudah konsepBencana dalam konteks ini adalah ancaman yang berasal dari kekuatan supranatural yaitu Tuhan atau Dewa.

\section{Pupuh Sinom Dalam Serat Sabdo Palon}

Serat Darmogandul merupakan serat yang ditulis oleh Kalamwadi, yaitu dokumentasi berupa tembang (Pupuh-Sinom) yang berisi pembicaraan antara Brawijaya V (Bhre Kertabumi), Sunan Kalijaga dengan Abdi Dalem Sabdo Palon dan Naya Genggong. Dialog ini terjadi padamasa-masa akhir kerajaan Majapahit yaitu masa ketika Brawijaya menerima ajaran Islam menjadi agama kerajaan.Secara politik, kekuasaan Majapahit dapat ditaklukan oleh pasukan Islam. Proses islamisasi berjalan sangat halus. Peristiwa Raja Brawijaya V memperistri keturunan Cina yang telah lebih dulu muslim, yaitu Putri Tan Eng Kian dan Dewi Anarawati, dapat dijadikan fakta penjelas bagaimana proses islamisasi di Kerajaan Majapahit berjalan.

Inti pembicaraan berlangsung ketika Brawijaya bertanya kepada Sabdo Palon tentang Brawijaya yang telah masuk Islam. Sabdo Palon menyatakan bahwa dirinya tidak mau masuk Islam sebagaimana Brawijaya karena posisinya sebagai pembesar dan pengayom raja-raja di seluruh tanah Jawa. Sabdo Palon menyatakan antara dirinya dengan Brawijaya tidak bisa disatukan lagi maka satu-satunya jalan bagi keduanya adalah berpisah. Sebelum berpisah Sabdi Palon menyampaikan janjinya (ancaman) akan kembali 500 tahun yang akan datang untuk mengganti agama yang dibawa para wali ini dengan agama "Budi". Bahkan ia mengancam akan menghancurkan sehancurhancurnya. Sabdo Palon tidak puas jika belum melihat Agama "Budi" kembali tersebar di tanah Jawa.

Selanjutnya Sabdo Palon mengutarakan ciri-ciri kedatangannya berupa tandatanda alam, yaitu rangkaian peristiwa alam atau bencana seperti banjir besar, gunung meletus, dan wabah. Berdasarkan pembicaraan antara Sabdo Palon dan Syeh Subakir dapat diambil satu simpulan bahwa yang dinamakan bencana adalah situasi dimana Sabdo Palon, kembali ke Tanah Jawa ketika praktek agama baru (Islam) sesuai dengan apa diinginkan Sabdo Palon. Artinya, Sabdo Palon sebenarnya tidak akan kembali jika agama yang dibawa Syeh Subakir berjalan sesuai dengan yang diharapkannya. Menurut penulis Sabdo Palon sedang dan telah kembali berdasarkan karakter bencana yang kini terjadi, dengan indikasi-indikasiterjadinya tsunami, banjir, gunung meletus, dan sebagainya.

Sebagai suntingan teks agar kajian terfokus, maka akan disajikan satu bait lagu tembang Pupuh Sinom ini sebagai berikut.

Ngidul ngilen purugina, Ngganda banger ingkang warih, Nggih punika medal kula,Wus nyebar Agama Budi, Merapi janji mami, Anggereng jagad satuhu, Karsanireng Jawata, Sadaya gilir gumanti, Boten kenging kalamunta kaowahan. Adapaun arti dari bait ini adalah (lahar tersebut mengalir ke barat daya. Baunya tidak sedap. Itulah pratanda kalau saya datang untuk kembali menyebarkan agama Buddha. 
Kelak Merapi akan bergelegar. Itu sudah menjadi takdir Hyang Widhi bahwa segalanya harus berganti. Tidak dapat bila diubah lagi). Bait ini menjelaskan ruang dan waktu dimana Sabdo Palonakan datang, atau kembali yaitu 500 tahun yang akan datang, dalam suasana yang memprihatinkan seperti pemimpin tidak amanah. Secara lebih tegas Sabdo Palon menyatakan akan kembali dan menggantikan agama baru (Islam) jika ternyata ajaran Wali Songo ini tidak lebih baik Syiwa Buddha. Adapun tanda-tanda alam ditandai dengan aneka bencana mulai dari banjir, gempa, dan wabah.

Di poin ini dapat disampaikan definisi bencana sebagai ancaman berupa kerusakan yang disebabkan intervensi kekuatan supranatural dari sosok Sabdo Palon atau Semar Badranaya. Ancaman kerusakan (bencana) akan terjadi karena ulah manusia itu sendiri yang mengabaikan kata-kata Sabdo Palon 500 tahun yang lalu. Artinya jika manusia tidak melanggar atau menyimpang dari ajaran luhur bangsa Indonesia, maka ancaman atau bencana itu tidak akan terjadi. Jadi jika dilihat fakta antara nubuat Sabdo Palon dan keadaan atau kenyataan saat ini maka nubuat itu mendekati kebenaran. Fakta bencanasudah dijelaskan diatas. Benar atau tidak bahwa itu laku atau perbuatan Sabdo Palon sebagai fakta historik atau bukan, dapat diabaikan. Fakta itu dianggap benar sahsah saja. Poin dalampenelitian ini adalah sebuah penyimpangan dalam berbudaya akan menimbulkan bencana.

Persoalan selanjutnya adalah seputar nasib kekuasaan Jawa (Nusantara). Apakah para pemimpin atau pemangku kuasa di negeri ini telah menyimpang atau tidak amanah? Hal itu dapat terlihat pada,adanya kasuskorupsi oleh para pejabatadalah fakta yang tidak terbantahkan. Berikutnya soal praktik "ke-Islaman", seperti Islam diajarkan dengan cara-cara kekerasan bukan kerahmatan sebagaiman mestinya, nyata terjadidi depan mata. Islam yang semestinya rahmatan lil alaminn dihadirkan demikian mengerikan dan mengancam. Kelompok Islam yang tidak bertanggung jawab yang hanya mengedepankan doktrin dan pemahaman sempit, sebut saja ISIS, adalah salah satu contoh paling radikal. Praktik agama semacam ini, secara nyata menjadi penyebab Sabdo Palon kembali dari persembunyiannya dan menebar kerusakan sebagaimana yang diucapkan 500 tahun yang lalu.

Nilai-nilai ajaran Jawa kuno, tidak dirawat dengan baik bahkan telah disingkirkan. Sesuai janjinya,Sabdo Palonkembali mengajarakan ajaran Jawa Kuno. Di dalam Serat Darmogandul disebut agama Islam akan diganti dengan agama kawruh yang oleh kaum kristiani kawruh ditafsirkan sebagai agama Kristen (Anonim, 1958). Sementara dalam Serat Sabdo Palon versi Sunan Giri, agama yang dimaksud adalah agama Syiwa-Buddha. Terhadap teori yang terakhir, kebanyakan ahli setuju dengan tafsir ini karena Syiwa-Buddha sebagai agama campuran Hindu dan Buddha yang telah mengakar di Jawa (Shashangka, 2015).

\section{SIMPULAN}

Berdasarkan penelitian inidapat diambil satu temuan tentang Nubuat Bencana dalam Serat Sabdo Palon. Jika nubuat merupakan ancaman berarti ada pihak yang memberi ancaman. Pengancam adalah kekuatan supranatural (Tuhan, Dewa dan lain- 
lain) yang berada di luar kendali dan kekuatan manusia yang terbatas. Siapa yang diancam adalah manusia sebagai aktor alam raya yang diberikan amanah untuk memayu hayuning bawana artinya mempercantik yang sebenarnya sudah cantik di bumi ini. Bukan berbuat kerusakan karena keserakahan dan juga hawa nafsu, maka tugas seorang kejawen adalah keselamatan hidup alam Serat Sabdo Palon terkandung pesan mitigasi bencana yang akan sangat penting terlebih akhir-akhir ini bencana kerap melanda kita. Oleh karena itu, kita harus bijak menilai ini sebagai pelajaran dan penyadaran kultural lewat penghargaan akan nilai-nilai tradisional. Sesudahnya marilah kita senantiasa menjaga kehidupan sosial, ekonomi budaya ini dengan perilaku yang baik agar terhindar dari bencana ataupun marabahaya.

\section{UCAPAN TERIMA KASIH}

Terima kasih atas kesempatan yang baik ini karena bisa ikut bergabung dalam kebersamaan intelektual yang mendidik ini. Kebersamaan ini membuat saya dapat mengenal khasanah sastra Nusantara yang kaya. Penelitian Sastra Kuno yaitu Serat Sabdo Palon (Darmogandul) membangkitkan kerinduan pada kebudayaan lama yang terabaikan. Terima kasih kepada Balai Arkeologi Jawa Barat atas kebersamaan dan bimbingan kepenulisan ini. Mudah-mudahan karya ini dapat memberikan manfaat sebesar-besarnya bagi pengembangan ilmu pengetahuan dunia dan khususnya pengembangan Ilmu Pengetahuan di Indonesia. Amin.

\section{DAFTAR PUSTAKA}

Anonim, K. (1958). Darmogandul (5th ed.).

Azra, A. (2016). Transformasi Politik Islam (1st ed.). Prenadamedia Group. www.ppim.uinjkt.ac.id

Fathurahman, O. (2016). Filologi Indonesia: Teori dan Praktek (2nd ed.). Prenadamedia Group.

Kurniawan, H. (2020). Channel Kisah Tanah Jawa: Sabdo Palon dan Bumi Nusantara. (p. Part 2). https://www.youtube.com/watch?v=-mXuCx1rDrc

Palmer, R. E. (1972). Hermeneutics: Interpretation Theory In Schleier, Dilthey, Heidegger, and Gadamer (2nd ed.).

Purwadi. (2006). Babad Tanah Jawa: Menelusuri Sejarah Kejayaan Kehidupan Jawa Kuno (1st ed.). Panji Pustaka Yogyakarta.

Shashangka, D. (2015). Ilmu Jawa Kuno. Dolphin. www.kaurama.com

Shashangka, D. (2016). Sabdo Palon: Kisah Nusantara Yang Disembunyikan (S. Gh (ed.); 2nd ed.). Dolphin. www.kaurama.co.id

Susiyanto. (2012). Jangka Sabda Palon: Ramalan Kehancuran Islam di Jawa? Insist. https://insists.id/jangka-sabda-palon-ramalan-kehancuran-islam-di-jawa/

Zakaria J. Ngelow, A. R. (2019). Teologi Bencana: Pergumulan Iman dalam Konteks Bencana Alam (S. SB (ed.); 1st ed.). BPK Gunung Mulia. www.bpkgunungmulia.com 
Zuchdi, D., \& Afifah, W. (2019). Analisis Konten Etnografi dan Grounded Theory dan Hermeneutika dalam Penelitian. 1st ed. (R. Damayanti (ed.). Bumi Aksara. www.bumiaksara.com

\section{HASIL DISKUSI}

\section{Pertanyaan}

1. Nanang Saptono (Balai Arkeologi Jawa Barat)

Nubuat Sabda Palon semuanya cenderung meninggalkan pesan kebencanaan yang mengancam atau lebih tepat sebagai ancaman, artinya sesuatu yang bersifat negatif. Tapi kita juga punya ramalan sebagaimana nubuat tadi yaitu ramalan Jayabaya yang sifatnya positif. Tadi ada makna bahwa munculnya Sabda Palon karena pemberontakan dari kaum yang terpinggirkan, menurut penulis bagaimana dengan ramalan Jayabaya?

\section{Jawaban}

1. Yang di nubuatkan oleh semar lebih sebagai suatu ancaman, kenapa saya menyebut ini sebagai mengancam? Dalam perspektif politik, status quo (Kerajaan Majapahit sebagai kerajaan Hindu-Buddha) ingin terus berkuasa. Hal tersebut sangat normal. Sama halnya dengan budaya. Semar adalah sosok yang mengalah dan menantang, bila terjadi sesuatu terjadi pada masa depan maka dia akan datang dalam bentuk lain baik itu dalam wujud bencana, mulai dari banjir, gunung meletus atau bahkan wabah dan lainnya. Tidak semua yang dicontohkan Jayabaya adalah hal yang positif, contohnya ramalan wanita yang menyerupai pria, atau besi yang bisa terbang, itu merupakan contoh negatif. 